\title{
Publisher Correction: Seeded X-ray free-electron laser generating radiation with laser statistical properties
}

Oleg Yu. Gorobtsov, Giuseppe Mercurio, Flavio Capotondi, Petr Skopintsev, Sergey Lazarev (D, Ivan A. Zaluzhnyy (D), Miltcho B. Danailov, Martina Dell'Angela, Michele Manfredda, Emanuele Pedersoli (D), Luca Giannessi, Maya Kiskinova (1), Kevin C. Prince (B), Wilfried Wurth \& Ivan A. Vartanyants (D)

Correction to: Nature Communications https://doi.org/10.1038/s41467-018-06743-8, published online 29 October 2018.

In the original version of the Article, the horizontal axis labels of Figure $4 \mathrm{~d}$ incorrectly read ' $0,05,100$ ' instead of the correct ' 0 , 50 , 100'. This has been corrected in both the PDF and the HTML versions of the Article.

Published online: 13 November 2019

(c) (i) Open Access This article is licensed under a Creative Commons Attribution 4.0 International License, which permits use, sharing, adaptation, distribution and reproduction in any medium or format, as long as you give appropriate credit to the original author(s) and the source, provide a link to the Creative Commons license, and indicate if changes were made. The images or other third party material in this article are included in the article's Creative Commons license, unless indicated otherwise in a credit line to the material. If material is not included in the article's Creative Commons license and your intended use is not permitted by statutory regulation or exceeds the permitted use, you will need to obtain permission directly from the copyright holder. To view a copy of this license, visit http://creativecommons.org/licenses/by/4.0/.

(C) The Author(s) 2019 